\title{
PROPOSED FLOOD REACTION MODEL FOLLOWED BY THE EVACUATION OF THE POPULATION IN V4 COUNTRIES
}

\author{
DANIEL BREZINA ${ }^{1} \&$ KATARÍNA HOLLÁ ${ }^{2}$ \\ ${ }^{1}$ Armed Forces Academy of General Milan Rastislav Štefánik, Slovakia \\ ${ }^{2}$ Faculty of Security Engineering, University of Žilina, Slovakia
}

\begin{abstract}
In the last few years, the number and severity of natural disasters is growing, especially floods. This phenomenon does not bypass V4 countries. Lower government levels of crisis management are confronted with many requirements. Their objective is to ensure the desired level of prevention of crisis events, as well as the ability to effectively respond to real threats to residents and property. This is associated with the need to optimally decide and subsequently effectively use the available resources needed to solve natural disasters. The main aim of this paper is to proposals flood reaction model followed by the evacuation of the population. The authors deal with the issue of optimizing decisionmaking processes, while emphasizing its practical application for lower government levels of V4 country (Slovak Republic, Czech Republic, Republic of Poland, and Republic of Hungary). The main reason for the focus of the paper is due to the constant increase in the number of floods in the countries of Central and Eastern Europe as well as the absence of the model in V4 countries. The paper is divided into a theoretical and practical part. The theoretical part contains a comparison of crisis management systems in V4 countries. The practical part consists of the processes and proposal of the flood reaction model followed by the evacuation of the population in the conditions of V4 countries. The model is shown in the form of an algorithm with a detailed defined analysis of the competence and tasks of lower government levels on a section of crisis management. For a better view, the model is divided into three logically and methodically follow-up phases.

Keywords: crisis management, floods, evacuation, decision-making process, authorities, V4.
\end{abstract}

\section{INTRODUCTION}

Deciding is a significant function of crisis management. Its importance is growing in the solving of crisis events. It is a difficult and challenging process that affects the nature of the crisis events itself. Crisis managers, individual bodies and public authorities, participating in the solutions of natural disasters are exposed to the media and inhabitants. These require a quick and effective response to extraordinary events that minimize damage and losses. Tasks of public administration, with an emphasis on local government level, in the solution of crisis events are extensive and complex. The main motivation for the selection of the chosen theme was the fact that there are many uncertainties and problematic areas that were not solved in the past. If we want to talk about the real optimization of crisis management decision-making processes at operational level, it is necessary to clearly define their roles and competences and propose effective measures applicable to practical conditions.

\section{COMPARING CRISIS MANAGEMENT SYSTEMS IN V4 COUNTRIES}

Proposing a flood reaction model followed by the evacuation of the population in the V4 countries requires knowledge and relations that apply to V4 crisis management systems. Individual V4 countries were compared based on predetermined criteria. Crisis management systems in each country were influenced by historical assumptions as well as the species and characteristics of a crisis event with the most extensive impact on life, health, property, and 
the environment. This has led this to changes to the legal environment and adjustment of security documents in each country.

\subsection{Slovak Republic}

The Government of the Slovak Republic is in the highest position in crisis management system in the Slovak Republic. The Ministry of the Interior of Slovak Republic is the central authority of crisis management. The executive authority of the crisis management is the crisis staff. The crisis staff is not a permanent authority. It is activated only when there is a danger of a crisis situation or when a state of crisis is declared. Local government level (District Office) has a very important role in the process of solution of crisis events. The executive components of crisis management are Regional/District of the Police Force and Regional/ District Directorate of the Fire and Rescue Corps. The most competent institutions for solution of crisis events are the Integrated Rescue System. According to Šimák [1] the crisis management system uses mainly staff organizational structures. They form a special public authority, t. j. state administration (central and local) and self-government (regional and local). Powerful crisis management components must be able to intervene immediately at a particular place with the necessary capacity of human and technical means, including adequate technology. It is essential that all powerful crisis management components have clearly defined competencies allowing intervention in any environment.

Local government level authorities, in particular District Offices, manage selected segments of state administration, including crisis management section. Effective reaction to crisis events, especially on natural disasters, requires unambiguous determination of responsibility and tasks at lower levels of management. Neubauerová and Dubrovina [2] characterizes local government level as a state budgetary organization. It is linked to the Ministry of Interior of the Slovak Republic through financial relations. Local government authorities are a hierarchical lower level of state administration.

There are several legislations in the prevention and resolution of crisis events. These include two constitutional acts, 23 acts and more than 10 decrees issued by various ministries. In the Slovak Republic, the Integrated Rescue System was set up in 2002 because of the European Union's experiences. The main purpose was to increase the quality of rescue activities. According to Act no. 129/2002 Coll. about the integrated rescue system [3], as amended, the Integrated Rescue System ensures rapid use and coordination of rescue and rescue entities in the event of a risk of crisis event or during its solution.

The effective crisis management process requires the determination of tasks and determine the responsibility of authorities and institutions in the crisis management system at all government levels, especially at lower government levels. Constitutional Act no. $227 / 2002$ Coll. on state security at war, state of war, state of exceptional and state of emergency, as amended [4], defines states of crisis resulting from the name of the constitutional act, including the authority responsible for its declaration. This Constitutional Act defines and provides for the competence, responsibility, and action of constitutional authorities during the declaration of a particular state of crisis, including the implementation of the tasks of the Security Council established in the relevant territorial unit (district, county, state). The purpose of Act no. 42/1994 Coll. on civil protection of the population, as amended [5], is to establish tasks and scope of state administration authorities, self-governing regions, and municipalities in the field of civil protection of population, including law and obligations of legal persons in ensuring civil protection of the population. This act contains details of the announcement of the emergency in terms of its nature and scope of the negative consequences of crisis event within different territorial districts (municipality, district, region, state). This 
act also describes the principles of governance, organization, and implementation of rescue work. A substantial part of Act no. 387/2002 Coll. on the governance of the state in crisis situations outside the time of war and state of war, as amended [6], is dedicated to issue of public authorities is devoted to public authorities. This act defines crisis management authorities and sets out tasks within their scope. The position of the forces and means in the crisis management system does not occur in any of the three-above legislation in issue of crisis management. The District Office is responsible for several segments of state administration, including a section of crisis management. They are governed by acts and lower legislation in its activities. These create space for an effective and effective reaction to crisis events, with an emphasis on natural disasters.

\subsection{Czech Republic}

Extensive floods in the Czech Republic in 1997, resulted in a change in the legal environment in crisis management, including the perception of crisis management by not only competent authorities, but also by the public. The impact of these floods led to the creation of a specific legal framework, t. j. Act no. 240/2000 Coll., on Crisis Management and amending certain acts, as amended (the so-called Crisis act). The basic aim of this act was the definition of all entities, authorities and institutions that are directly or indirectly involved in the prevention, progress and disposal of the impacts caused by extraordinary events [7], [8]. According to Vaníček [9] a legal environment in the field of crisis management in the Czech Republic does not specify the differences between the term crisis, an extraordinary situation, and an extraordinary event. However, on closer examination, it is possible to find differences mainly based on the possibility of threats for the existence of the state and life of the nation.

In the case of a threat or creation of a crisis event and in direct dependence on its character, a crisis state is declared. Its fundamental aim is a legal confirmation of changes to the competences of individual crisis management authorities. The right to declare state of crisis only have crisis management authorities. The government of the Czech Republic may declare a state of emergency in the case of natural disasters, ecological accidents, industrial accidents, and other dangers. Parliament of the Czech Republic on a proposal for the Government of the Czech Republic may declare a state of threats to the state if the sovereignty or territorial integrity of the state is endangered [10]. It is possible for crisis management authorities in the Czech Republic to consider all the authorities that ensure the analysis and evaluation of possible endangerment of its security, planning, implementation, and control of activities carried out in the context of the prepared measures as well as solution of crisis situations [11], [12]. Security councils and crisis staffs belong to crisis management. Security councils is to coordination instruments in the process of solution crisis events. Crisis staffs can be as advisory employment authorities established by the government, region, or municipalities [10].

The main role of the Government of the Czech Republic in the crisis management system in the Czech Republic is to correction for various crisis events through other crisis management authorities. It has certain powers depending on the nature of the declared state of crisis. For example, the Government of the Czech Republic may set out to what extent and for which some civil rights will be limited. The Government of the Czech Republic implements specific economic or regulatory measures [13].

Territorial self-government authorities have its justification in the crisis management system in the Czech Republic based on the delegated competence. County authorities (Regional president and Regional Office) ensure the preparedness of the crisis, the preparation of rescue work and the protection of the population. Region Security Council is 
the working authority of regional president. At the same time, it is also a coordinating authority in preparing the region on crisis events. The Regional Office organizes and ensures synergies and cooperation between the Municipality Office and other competent authorities and municipalities in the region.

Municipality authorities (Mayor of Municipal and Municipal Office) ensure the preparedness of the municipality to address crisis situations and perform activities to mitigate their impacts, within its territorial scope. The Mayor of Municipal sets up and manages crisis staff (municipal work authority). The Municipal Office provides synergies to the Regional's fire-rescue service in the processing of the crisis plan of the region and the municipal crisis plan [11].

\subsection{Republic of Poland}

According to Dworzecki [14] the crisis management system in the Republic of Poland is relatively complicated and demanding. History of the formulation of this type of structure in the Republic of Poland is the best proof. The shortcomings of systemic solutions allowing the coordination of activities of all subjects that form various rescue structures were found during large floods in July 1997. As Lizak [15] writes the crisis management system in the conditions of Republic of Poland is the civilian component of the national security system. It is a response to various internal and external threats such as natural disasters and terrorism. Individual competences and tasks are regulated and defined in the Constitution of the Republic of Poland [16] some of the acts and internal procedures of governing authorities at different government levels.

The Government of the Republic of Poland is a crucial element and is responsible for maintaining public order and internal security at national level. Within the Government of the Republic of Poland, the Governmental Crisis Management Team is established by the Minister of Interior and Administration of the Republic of Poland. Most of the rescue components is subordinate to the Ministry of the Interior and Administration of the Republic of Poland, which is responsible for maintaining public order, protection of population in crisis situations, including disaster prevention and crisis situations. Other rescue components are subordinated to the Government Centre for Security. The structure of fire components and civil protection components are united into one unit [17].

The 11th Chapter of the Constitution of the Republic of Poland [16] deals with the issue of extraordinary measures. State of exceptional, state of emergency or state of natural disasters can be declared in situations of special danger and where constitutional measures are insufficient (Article 228). The Government of the Republic of Poland may declare the state of natural disasters in a particular area or throughout the Republic of Poland longest for 30 days. During this time, it is necessary to minimize the impacts of natural disasters or technological accident (Article 232). The issue of crisis management system in the Republic of Poland is described in more detail in Act of 26 April 2007 on crisis management [18]. The authorities responsible for crisis management, their roles and competences, as well as the rules for the financing of crisis management tasks are contained in this act (Article 1).

According to Zdzymira and Rozwadowski [19] a structure of temporary crisis management authorities (teams and centres) obliges the competent authorities to make crisis management teams in suitable regime. It is a principle that in great territorial units (for example, in larger cities, especially in the voivodes), crisis management centres operate as a whole. These work continuously at relevant levels of crisis management. 


\subsection{Republic of Hungary}

The last characterized system of crisis management is a crisis management system in the Republic of Hungary. Frequent disasters occurring in recent years in the territory of the Republic of Hungary caused the crisis management system in the Republic of Hungary to be exposed to great pressure. Petkov and Tagarev [20], for one of the most famous and the most tragic exceptional events, it considers the red sludge leak from the ruptured dam of the aluminium sludge pond near the village of Ajka in 2010. Following this event, the new Act was adopted in 2011 Act no. 128 on disaster management [21]. Its main goal was to increase the efficiency of the National Disasters Management System in the Republic of Hungary and improving protection measures against risks caused by nature or human. This act laid the basis of the cooperation system of crisis management authorities with the structures of compulsory and voluntary components of civil protection [17].

National Directorate General for Disaster Management (NDGDM) obligations and competences (NDGDM) are clearly defined in Act no. 128 on disaster management. The basic function of NDGDM is the protection of lives and property of the population living in the Republic of Hungary, including the protection of critical infrastructure elements. Its main mission is the prevention of disasters and the implementation of rescue actions in civilian emergency situations. The new organizational structure is based on three pillars, specifically civil protection, fire protection and industrial security [20], [21].

On 25 April 2011, a new basic act was adopted by the Republic of Hungary, in which various crisis conditions are described. The Government of the Republic of Hungary may declare the state of danger in the case of a natural disaster or industrial accident that threatens the life and property of the population, or to mitigate its impacts (Article 53). All activities and tasks are coordinated at the level of the region in case of threat to extensive territory or where local forces and means designed to address crisis events are insufficient. The Government of the Republic of Hungary has responsibility for managing during crisis events that negatively affect multiple districts or which cannot be controlled at the region level [21].

The Mayor of the Municipality is responsible for preparing for the protection against disasters and guiding activities in the process of solution of crisis events at local government level within its territorial scope. The Committee on Local Defence coordinates and manages all measures and activities in the event of a threat to the exceeding territory of individual parts within the municipality. The main responsible person is the mayor and other members of this committee are mayors of city parts. They carry out their activities with the support of District Directorate of Disaster Protection. The leaders of regional and local governments (Presidents of the General Assembly of Regional and Mayors) have responsibility for planning, organizing, managing, and implementing elements of critical infrastructure and assistance to the population for extraordinary events [17].

\section{DATA AND METHODOLOGY}

The main aim of this paper is the processing and proposing a flood reaction model followed by the evacuation of the population for V4 countries. The main methods include analysis, comparison and algorithmic procedures. The content of the methodology is an analysis of individual crisis management systems in V4 countries and their subsequent comparison through the selected characteristics of these systems. Currently, there exist many scientific and research methods, techniques and procedures. Models or algorithms used to optimize decision-making processes can be created through them. Algorithmic procedures were used in the processing of the flood reaction model followed by the evacuation of the population for V4 countries. 


\section{PROPOSED OF DECISION-MAKING PROCESSES OF THE FLOOD REACTION MODEL FOLLOWED BY THE EVACUATION OF THE POPULATION FOR V4 COUNTRIES}

Ensuring effective evacuation of the population due to flood is a specific and problematic area, especially at lower levels of crisis management. Individual municipalities and cities plan to declare and manage evacuation in their territory through developed evacuation plans. At first, the expected progress of the flood development needs to be assessed. It consists of five steps:

1. Cause of origin of flood (long-lasting rainfall, intensive rainfall, melting snow or current occurrence of these causes);

2. Gradual rise of the river level to the maximum capacity of the water flow river;

3. Exceeding the capacity of the watercourse bed by the water flow;

4. Drop in water level below to the maximum capacity of the water flow river;

5. Normal flow of the river bed without the possibility of flood risk.

In terms of individual phases of the flood reaction model followed by the evacuation of the population for V4 countries, the progress of the flood development is shown in Fig. 1.

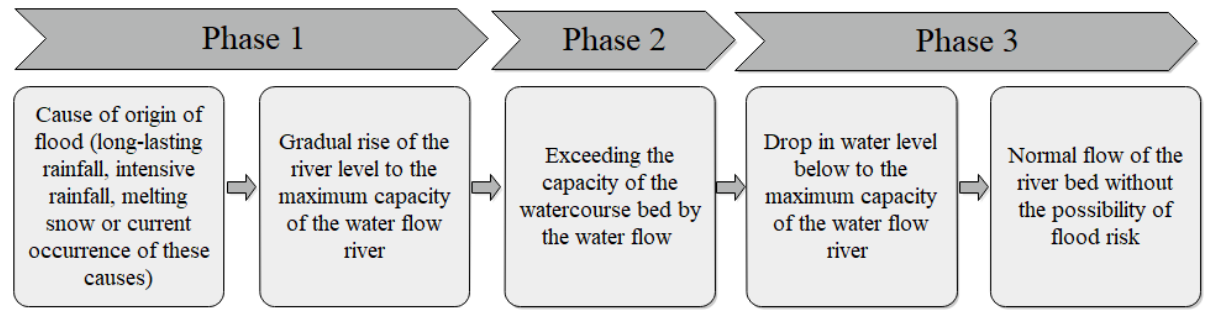

Figure 1: Expected course of flood development.

Decision-making process of phase 1 of the flood reaction model followed by the evacuation of the population for V4 countries is illustrated in Fig. 2. Phase 1 of the model begins at the lowest level of crisis management. The municipal receives information about the possibility of developing floods or its inception based on a gradual rise of the river level to the maximum capacity of the water flow river. This is preceded by an assessment the cause of origin of flood. Individual municipalities commission needed for a solution floods are activated depending on the intensity of flood effects. Their activation will already be carried out in the activation of the warning and notification network, or after the assessment and evaluation of the situation at the municipal crisis staff meeting. The mayor of the city/village envoys an exploration-monitoring group endangered area or location of the occurrence of flood. The municipality declares a state of crisis based on information from the explorationmonitoring group or the results of the decision of the members of the municipality crisis staff. In the case of flood, it is necessary to distinguish three degrees of flood activity with a subsequent state of crisis statement in the local government. The municipality declares or recalls of individual degrees of flood activity in the case of flood in its territory. The municipality shall inform about declaration or recall of the state of crisis and individual degrees of flood activity to the relevant higher level of crisis management (in the figures marked of abbreviation of HLCM). All the necessary authorities and crisis management subjects, including human and material resources needed to solution of floods, is activated after informing about state of crisis. 


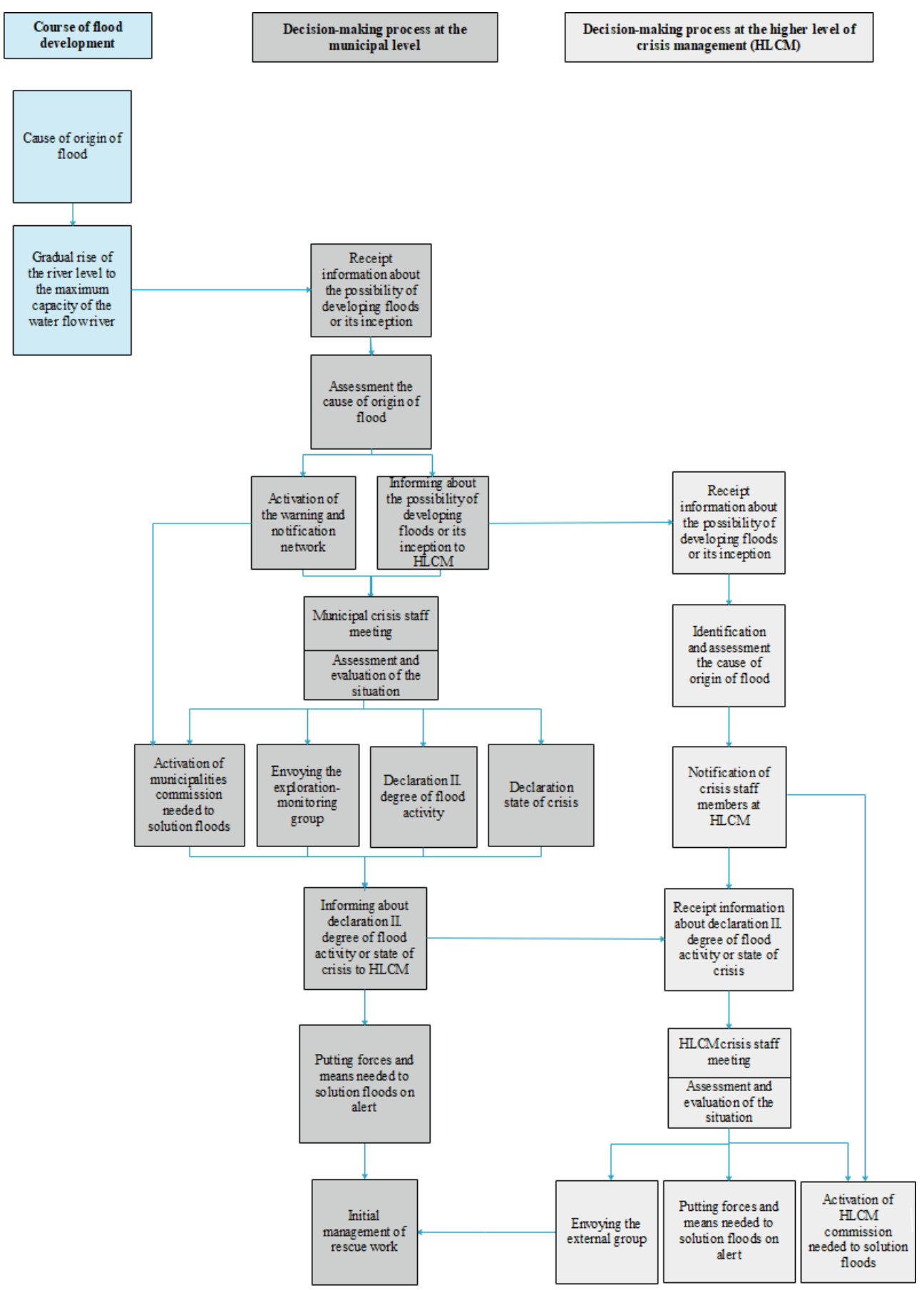

Figure 2: Decision-making process of phase 1 of the flood reaction model followed by the evacuation of the population for V4 countries. 
Fig. 3 detail shows phase 2 of the flood reaction model followed by the evacuation of the population for V4 countries. In terms of the course of developing floods, the model starts exceeding the capacity of the watercourse bed by the water flow. Following the assessment and evaluation of the situation at the municipal crisis staff, it is necessary to declare III. degree of flood activity regarding the course of the flood development. The receipt information about declare III. degree of flood activity from the municipality is the beginning of decision-making process at a higher level of crisis management. In case of exceeding the territorial unit of self-government due to the negative effects of floods, responsibility for crisis management in the endangered or affected area assumes the authority at a higher level of crisis management. The decision to ensure and perform the population evacuation is the role of crisis manager, respectively the manager at a higher level of crisis management. Organization and management of the course of evacuation of the population in the process of a flood solution consists of three gradual steps:

- Managing and guidance of evacuants movement to the evacuation centre, including informing of the evacuation centre about the status and progress of the evacuation of population;

- Organizing and managing the of evacuants movement from the evacuation centre to the emergency accommodation place, including informing of the evacuation commission about the activities of the evacuation centre;

- Organizing and ensuring the involvement of evacuants into the emergency supply system, including informing of the evacuation commission about the activities of emergency accommodation place.

The last phase of the model is conditioned by reducing the risk of flood for inhabitants. In this case, it is a drop in water level below to the maximum capacity of the water flow river (Fig. 4). Information about the development of floods from the exploration-monitoring group are a decisive basis of decisions about recall III. degree of flood activity and subsequent declaration II. degree of flood activity. The mayor of the municipality changes the degree of flood activity after assessment and evaluation of the situation at the municipal crisis staff. Upon receipt of information on the change in degree flood of activity, the crisis staff will meet at a higher level of crisis management. Based on the assessment and evaluation of the situation, crisis manager (or the manager at a higher level of crisis management) decides to prepare the measures that will allow the fastest return to normal stabilized state. The implementation of these measures is part of the recovery phase after the effects of floods. The preparation for these measures is carried out in the reaction phase on the flood. In this step decision process, the main task of the municipality is a supportive activity for a higher level of crisis management. They are involved in checking the functionality of equipment providing distribution of energy, water, and gas. After updates to other information from the exploration-monitoring group, the mayor of the municipality recalls II. degree of flood activity and declare I. degree of flood activity. If the situation is allowed this, I. degree of flood activity does not declare, but directly recalls state of crisis. After withdrawal forces and resources needed to solution the flood, the last step of the decision-making process municipality follows. This step is to inform about the change degree of flood activity of all the necessary authorities and institutions, including authorities at a higher level of crisis management. After receipt of the information about recall II. degree of flood activity or recall of state of crisis in the territory of the municipality, it follows of the issuing an order to ending work in the area affected by the flood. 

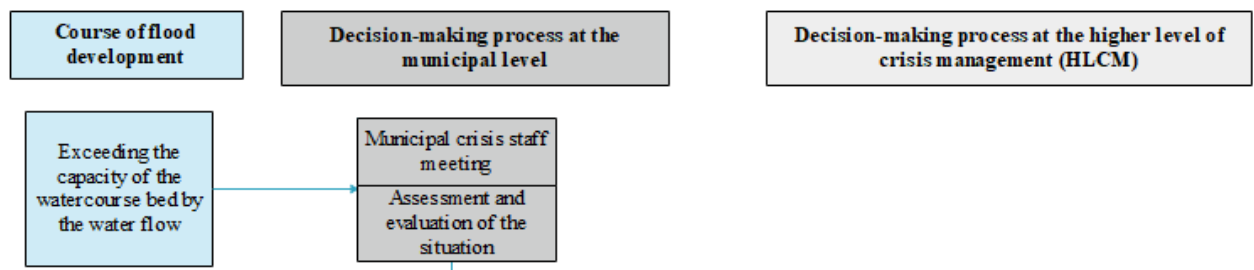

\begin{tabular}{|l|}
$\begin{array}{c}\text { Muricipal crisis staff } \\
\text { meeting }\end{array}$ \\
\hline $\begin{array}{c}\text { Assessment and } \\
\text { evaluation of the } \\
\text { situation }\end{array}$ \\
\hline
\end{tabular}
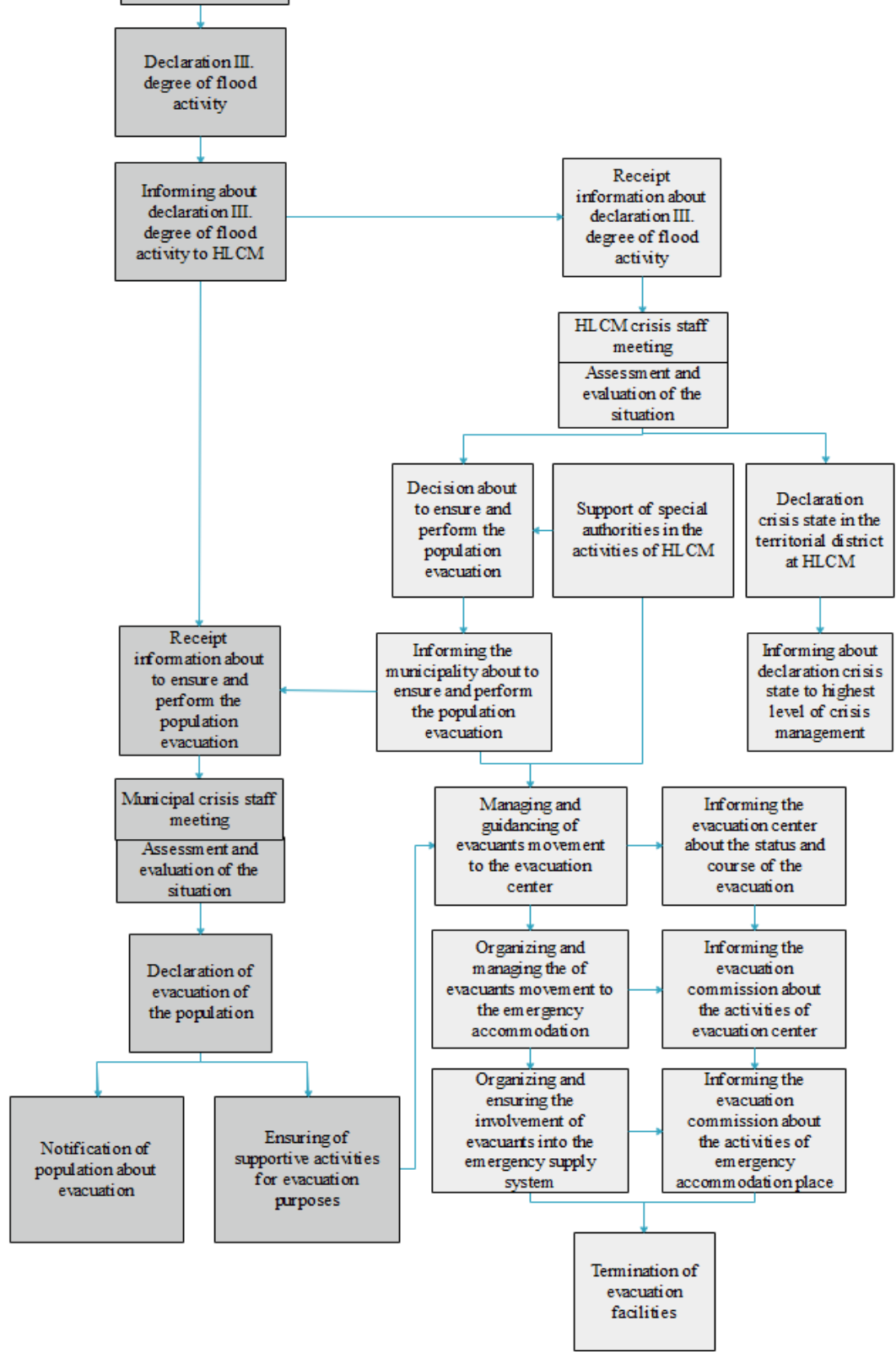

Figure 3: Decision-making process of phase 2 of the flood reaction model followed by the evacuation of the population for V4 countries. 


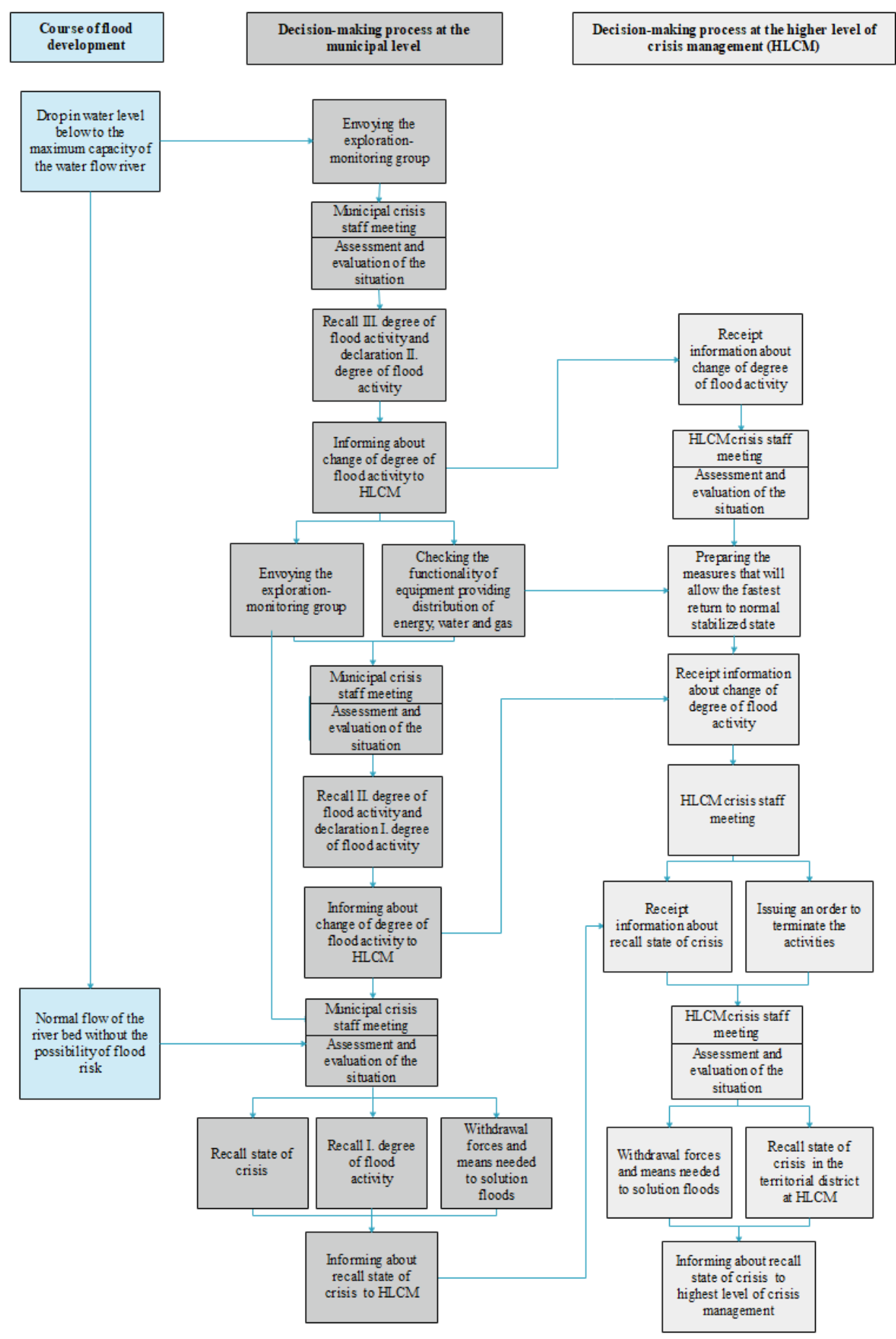

Figure 4: Decision-making process of phase 3 of the flood reaction model followed by the evacuation of the population for V4 countries. 


\section{CONCLUSION}

Based on the understanding of the current state of crisis management systems in V4 countries, it was possible to propose an effective and efficient flood reaction model followed by the evacuation of the population for V4 countries. This model is adapted to the requirements determined by the flood, including the nature of rescue work, with the subsequent necessary process of evacuating the population from the affected area. Crisis management cross-border cooperation between V4 countries must continue to be strengthened and streamlined. Crisis management authorities at all government levels, in particular in the area of border between countries, must be aware of crisis situations risks even beyond those countries whose negative effects and impacts can endanger their own populations and territory.

In addition to the faculty experts of the Faculty of Security Engineering of the University of Žilina and Department of Safety and Defence of Armed Forces Academy of General Milan Rastislav Štefánik, the authors had the opportunity to communicate with many experts from various domestic and foreign institutions dealing with crisis management issues. An essential contribution to the creation of theoretical and practical part of the paper was participation at foreign stages, namely in Tadeusz Kościuszko Land Forces Military Academy in Wroclaw and the Occupational Safety Research Institute in Prague. Other institutions with authors cooperated, they also include the Academy of Police Corps in Bratislava and the 5th Special Purpose Regiment in Žilina.

\section{ACKNOWLEDGEMENT}

This research was funded by Research and Education Grant Agency in Slovak Republic, grant number VEGA 1/0581/19 Stating the Social and Individual Risk of Employees and Public Resulting from Impacts of the Domino Effects Caused by Industrial Accidents and Methods of Reducing their Possible Escalation.

\section{REFERENCES}

[1] Šimák, L., Krizový manažment vo verejnej správe [Crisis Management in the Public Sector]. Druhé prepracované vydanie [2nd revised ed.]. EDIS: Žilina, 2016.

[2] Neubauerová, E. \& Dubrovina, N., Verejná správa v slovenskej republike - aktuálne problémy [Public administration in the Slovak Republic - current problems]. Public Administration, 2010.

[3] Act no. 129/2002 Coll. about the Integrated rescue system, as amended (Slovak Republic).

[4] The Constitutional Act no. 227/2002 about state security in time of war, state of war, state of exceptional and state emergency (Slovak Republic).

[5] Act no. 42/1994 Coll. about civil protection of the population, as amended (Slovak Republic).

[6] Act no. 387/2002 Coll. about state management in crisis situations outside the time of war and state of war, as amended (Slovak Republic).

[7] Veishar, A., Krajina, lidé a povodne v povodí řeky Moravy spoločnosti [Landscape, People and Floods in the Morava River Basin of Society]. Regiograph: Brno, 131 pp., 2002.

[8] Brázdil, R., Historické a současné povodně v České republice [Historical and Current Floods in the Czech Republic]. Masaryk University in cooperation with Czech Hydrometeorological Institute in Prague: Brno, 369 pp., 2005. 
[9] Vaníček, J., Právni úprava krizového řizení v ČR: vybrané problémy právní teorie $i$ praxe [Legal Regulation of Crisis Management in the Czech Republic: Selected Problems of Legal Theory and Practice], 1. vydanie [1st ed.], Eurolex Bohemia: Prague, 402 pp., 2006.

[10] Constitutional Act no. 300/2000 Coll., amending Constitutional Act no. 1/1993 Coll., The Constitution of the Czech Republic, as amended by Constitutional Act no. 347/1997 Coll., and Constitutional Act No. 110/1998 Coll., about the security of the Czech Republic (Czech Republic).

[11] Act no. 430/2010 Coll. about crisis management - Crisis Act, as amended (Czech Republic).

[12] Horák, R., Krč, M., Ondruš, R. \& Danielová, L., Průvodce krizovým ř́zením pro veřejnou správu [Crisis Management Guide for Public Administration], 1. vydanie [1st ed.], Linde: Prague, 407 pp., 2004.

[13] Antušák, E. \& Kopecký, Z., Úvod do teorie krizového managementu [Introduction to the Theory of Crisis Management], 2. vydanie [2nd ed.], University of Economics in Prague, Faculty of Business Administration, Department of Management, Crisis Management Section: Prague, 95 pp., 2003.

[14] Dworzecki, J., Crisis management system in Poland. The Science for Population Protection, Vol. 2, 2012. http://www.population-protection.eu/prilohy/casopis/eng/ 11/52.pdf. Accessed on: 18 Jun. 2021.

[15] Lizak, S., Critical infrastructure protection in Poland. Population Protection 2007, Ostrava, pp. 192-197, 2007.

[16] The Constitution of the Republic of Poland of 2nd April 1997. Dziennik Ustaw [Journal of Laws]. no. 78. item 483 (The Constitution of the Republic of Poland).

[17] International CEP Handbook, Civil Emergency Planning in the NATO/EAPC Countries, Swedish Civil Contingencies Agency (MSB), 2009.

[18] Act of 26th April 2007 about Crisis Management (Republic of Poland).

[19] Zdzymira, M. \& Rozwadowski, P., Emergency management process at a voivodeship level according to the Emergency Management Act of 26 April 2007. Przedsiębiorczość I Zarządzanie 2017 [Entrepreneurship and Management 2017]. SAN, 18(5). pp. 53-72, 2017.

[20] Petkov, V. \& Tagarev, T., Hungary: Capabilities, Organisations, Policies, and Legislation in Crisis Management and Disaster Response, Institute of Information and Communication Technologies/Centre for Security and Defence Management: Sofia, Number 127, 2015.

[21] Act no. CXXVIII of 2011 about Disaster management and related amendments to certain acts (Republic of Hungary). 